\title{
REGULARARTICLE \\ INFLUENCE OF ANTIOXIDANTS AND SALINITY STRESS ON SEED VIABILITY CHARACTERS OF SOME WHEAT CULTIVARS
}

\author{
A. A. KANDIL ${ }^{1}$, A. E. SHARIEF ${ }^{*}$, ALKHAMSA K. D. BOTABAAH ${ }^{2}$ \\ ${ }^{1}$ Department of Agronomy, Faculty of Agriculture, Mansoura University, 35516, Egypt \\ ${ }^{2}$ Faculty of Agriculture, Omar El-Moktar, El-Beda University, Libya
}

\begin{abstract}
To explore the impact of antioxidants types and levels prim on seed germination characters of some bread wheat cultivars under salinity stress. An experiment accompanied in seed science lab during November and December 2016, to study the response of antioxidants seed prim of some bread wheat cultivars to germinate under salinity levels. The highest of final percentages of germination (96.8\%), higher percentages of germination energy (58.11\%), highest values of germination index (0.970) and a smaller amount of germination time (2.29 d) obtained from sown Misr 1 variety. The results showed that maximum of percentages of germination $(91.15 \%)$ and germination index (0.951) obtained from soaking in humic acid. The maximum percentages of energy of germination (41.21\%) and the less mean germination time $(2.77 \mathrm{~d}$ from soaking grains in ascorbic acid compared with without antioxidants. Increasing antioxidant concentrations to 200 ppm produced the highest percentages of germination (91.61\%), energy of germination (37.63\%), germination index (0.953) and the lowermost of mean germination time (2.97 d) compared with without antioxidants and level of $100 \mathrm{ppm}$. Increasing salinity to $160 \mathrm{mmol}$ during germination of wheat cultivars significantly reduced percentages of germination by $18.5 \%$, energy of germination by $96.7 \%$, germination index by $18.6 \%$ and mean germination time by $53.5 \%$ compared with without salinity (control). Whereas, for reducing the gap between production and consumption, it could be recommended that soaking bread wheat in humic acid or ascorbic acid at $200 \mathrm{mmol}$ under salinity stress enhanced seed viability and advise to sown under saline new reclaimed soil.
\end{abstract}

Keywords: Wheat cultivars, Antioxidants, Salinity levels, Germination parameters

\section{INTRODUCTION}

Salinity as abiotic stress influenced wheat production of arid and semi-arid area in Egypt and Libya, under drought and salinity soil conditions. Salinity affected by seed germination, seedling establishment and plant growth. More than 900 million hectares of land worldwide, about $20 \%$ of the total agricultural land [1]. To overcome the shortage of wheat production of Egypt, to reducing the requirement on imported bread wheat through enhancing the production of grain yield per untie area by planting the modern cultivars tolerant to salinity in new reclaimed soil or irrigated with saline water and with drought.

An abiotic stress signal transduces via $\mathrm{ABA}$, calcium and hydrogen peroxide, which might induce antioxidant enzymes and pathways [2]. Seed priming with various agents can provide stress tolerance and high germination percentage in plants [3, 4]. The highest seed percentage germination and rate recorded from prime seeds with $0.00001 \mathrm{mmol}$ Salicylic acids [5]. Salicylic acid at low levels of salinity stress reduced germination time. Soaking seed in increased seed germination percentage salicylic with $0.7 \mathrm{mmol}$, the best results obtained from low levels of stress [6]. Enhancement of seed germination observed with humic acid application under drought stress [7].

The most tolerant to salinity recorded from Sakha 8, Sakha 93 and Kharchia varieties. Genotypes differed from salt tolerance observed as Sids 1, Gemmieza 7 and Westonia. Drysdale and Sakha 69 ranked as moderate tolerant. However, the rest genotypes recorded the lowest to salinity tolerance [8]. At higher levels of salinity inhibits percentage of germination or encourages a state of dormancy at low levels [9]. The more sensitive to the germination stage recorded from Zarlasht cultivar [10]. HD-2689 cultivar recoded the greatest germination percentage of all the treatments and HOW-234 cultivar recorded the highest at $150 \mathrm{mmol}$ salinity level [11]. The highest tolerance cultivars to salinity recorded from Hamoon, Sorkhtokhm and Bolani cultivars than the others [12]. Salinity increased the activity of antioxidant enzymes, but inhibit the antioxidant enzyme activities at high concentration or long-term of salt stress [13]. The highest tolerant to salinity were MBB cultivar and Waha cultivar recorded the lowest [14]. Salinity caused adverse effects on native seed than in breeder varieties [15]. Salinity level as

Received 11 September 2017; Accepted 28 December 2017

*Corresponding Author

\section{A. E. Sharief}

Department of Agronomy, Faculty of Agriculture, Mansoura University, Egypt

Email: shariefali42@gmail.com

(CThis article is open access and licensed under the terms of the Creative Commons Attribution License (http://creativecommons.org/licenses/by/4.o/) which permits unrestricted, use, distribution and reproduction in any medium, or format for any purpose, even commercially provided the work is properly cited. Attribution - You must give appropriate credit, provide a link to the license, and indicate if changes were made. 
low as $4 \mathrm{dSm}^{-1}$ and Zare cultivar recorded the highest germination percentage, however, the germination percentage of Pishgam, Zare, Sivand, Gascogen and Parsi cultivars were much reduced at moderate $\left(8 \mathrm{dSm}^{-1}\right)$ and higher (20 dSm-1) salinity levels [16-18]. The aims of this study were to estimate the effects of salinity and antioxidants on seed germination characters of some bread wheat cultivars.

\section{MATERIALS AND METHODS}

\section{Treatments and experimental design}

In seed lab, Agronomy Department, Faculty of Agriculture, Mansoura University, Egypt a laboratory experiment organized during November and December 2016, to study the reaction of antioxidants seed prim of some bread wheat cultivars to germinate under salinity levels. A factorial experiment in RCBD in four replication used. The four bread wheat cultivars, Miser-1, Miser-2 and Gemmiza-12 includes the first factor. The three types of antioxidants, Salicylic acid, Ascorbic acid and humic acid includes the second factor. The three concentrations of study antioxidants 0,100 and $200 \mathrm{ppm}$ include the third factor. The fourth factor include the five salinity levels $0,40,80$, 120 and $160 \mathrm{Mm}$. Selected cultivars obtained from wheat section, Field Crop Institute, ARC and stored under normal conditions in paper bags. Each cultivar was prim in the three antioxidants at above concentrations of $12 \mathrm{~h}$. Each cultivar irrigated with sodium chloride solution as above concentrations under the chamber condition at $25 \pm 1^{\circ} \mathrm{c}$ with darkness. Thereafter, seeds moistened with distilled water under control treatments. The prim seeds in antioxidants and non-primed seed of study cultivars sown in Petri dishes used fifty seeds per each treatment for each cultivar allowed to germinate on Petri dishes moistened with a water solution at five different $\mathrm{NaCl}$ concentrations except the control. The experiment consisted of 720 Petri dishes arranged in a factorial experiment in Randomized Complete Block Design (RCBD) at four replications the roll paper placed in a growth chamber for $12 \mathrm{~d}$ at $25^{-} \pm 1{ }^{\circ} \mathrm{C}$ for germination according to [19rules.

\section{Studied characters}

The bread wheat seed of study cultivars subjected for determination of germination characters in the laboratory experiment. Germination characters were estimated as follows:

1-The Germination Percentage [20, 21], energy of germination (EG) [21], germination Index (GI) [22] and mean germination time (MGT) [21] were calculated by standard methods.

\section{Experimental analysis}

The data collected was analysis, statistically by the analysis of variance technique using the MSTAT-C statistical package programmed as described by a procedure of [23]. The lest significant differences test (LSD) for 5 and $1 \%$ level of probability used for comparing between treatment means, according to [24].

\section{RESULTS AND DISCUSSION}

\section{Cultivars performance}

The results obtainable in table (1) clearly exposed that wheat varieties significantly differed in percentages of germination and energy of germination, germination index as well as mean germination time. The highest of final percentages of germination (96.8\%), higher percentages of germination energy (58.11 \%), highest values of germination index (0.970) and a smaller amount of germination time (2.29 d) obtained from sown Misre 1 variety. However, the lowest values of percentages of germination and energy of germination recorded from sown Misre 2 variety and the highest germination index and the longest of mean germination time recorded from sown Sakha 94 variety. Zarlasht cultivar appeared to be more sensitive to the germination stage [10]. HD-2689 cultivar recoded much germination percentage of all the treatments and HOW-234 cultivar recorded the highest at $150 \mathrm{mmol}$ salinity level [11]. Cultivars genetically differed from their resistance to salinity $[25,26]$. Similarly, other researchers $[27,28,29]$. found conclusions.

\section{Antioxidants effects}

The results accessible in table (1) clearly exposed that antioxidant types significantly differed in percentages of germination and energy of germination, germination index as well as mean germination time. The results showed that maximum of percentages of germination (91.15\%) and germination index (0.951) were obtained from soaking in humic acid. The maximum percentages of energy of germination (41.21\%) and the less mean germination time (2.77 d from soaking grains in ascorbic acid compared with without antioxidants. The results showed that maximum of percentages of germination (89.33\%) and energy of germination (28.75\%), germination index (0.933) and highest mean germination time (3.31 d) recoded from soaking grains in salicylic acid. Salicylic acid at low levels of salinity stress reduced germination time. Soaking seed in increased seed germination percentage salicylic with $0.7 \mathrm{mmol}$, the best results obtained from low levels of stress [6]. These explanations are reliable with those of [30], who reported that humic acid application partly reduced the final germination percentage, the inhibiting effect of salt on percentage of germination lessened in variable degrees by soaking in humic acid. Similarly, [31] reported conclusion on salicylic acid.

\section{Antioxidants concentrations effects}

Mean percentages of germination and energy of germination, germination index as well as mean germination time significantly influenced by antioxidant concentrations as revealed in table (1). Increasing antioxidant concentrations to $200 \mathrm{ppm}$ produced the highest percentages of germination (91.61\%), energy of germination ( $37.63 \%)$, germination index (0.953) and the lowermost of mean germination time (2.97 d) compared with without antioxidants and level of $100 \mathrm{ppm}$. Whilst, the lowest percentages of germination and energy of germination, germination index as well as the highest mean germination time recorded from without antioxidants (the control). Seeds prim with $50 \mathrm{ppm}$ Ascorbic acids and 50 ppm SA not only improved final germination count, but also reduced the germination time for saline conditions [3], who reported that prim seeds with $0.00001 \mathrm{mmol} \mathrm{SA}$ had the highest germination percentage and rate. The results are similar to those reported by other researchers $[6,7,32]$.

\section{Salinity stress effects}

Mean percentages of germination and energy of germination, germination index as well as mean germination time significantly influenced by salinity concentrations as revealed in table (1). Increasing salinity to $160 \mathrm{mmol}$ during germination of wheat cultivars 
significantly reduced percentages of germination by 18.5 $\%$, energy of germination by $96.7 \%$, germination index by $18.6 \%$ and mean germination time by $53.5 \%$ compared with without salinity (control). A similar conclusion reported by $[15,17,18,29,33]$.

\section{Interaction effects}

\section{Interaction between cultivars and antioxidants types effect}

The between cultivars and antioxidants types significantly affected percentages of germination and energy of germination, germination index as well as mean germination time. The results graphically demonstrated in Figs. 1, 2, 3 and 4 clearly indicated that the highest percentages of germination (97.5\%) and energy of germination (61.2\%), germination index (0.975) as well as mean germination time $(2.2 \mathrm{~d})$. Whilst, the deepest percentages of germination (80.6\%) produced from sown Misr 2 variety and soaking in ascorbic acid. The lowest percentages of energy of germination (14.26 \%) produced from sown Misr 2 variety and soaking in salicylic acid. Our results are in agreement with previous findings [27].

\section{Interaction between cultivars and antioxidant concentration effect}

With respect to the interaction between cultivars and antioxidants concentrations significantly affected percentages of germination and mean germination time, but insignificantly affected percentage of germination and germination index. The results graphically demonstrated in Figs. 5 and 6 indicated that highest energy of germination (60.7 \%), and the lowest of mean germination time (2.2 d) recorded from soaking Misr 1 variety in $200 \mathrm{mmol}$ of antioxidants. However, the less percentages of germination (20.2 5) from without antioxidant soaking of Misr 2 variety and the highest of mean germination time produced from without antioxidant soaking of Sakha 94 variety. Prim seeds with $0.00001 \mathrm{mmol} \mathrm{SA}$ had the highest germination percentage and rate [5]. The important of salicylic acid at low levels of stress, reducing the time of germination.

\section{Interaction between cultivars and salinity levels effect}

Regarding, the interaction between cultivars and salinity levels significantly affected percentages of germination and mean germination time, but insignificantly affected energy of germination and germination index. The results graphically demonstrated in Figs. 7 and 8 indicated that highest percentage of germination $(99.7 \%)$ produced from sown Sakha 94, Misr 1 and Misr 2 under the control (without salinity) and the lowest mean germination time (1.37) obtained from the control of Misr 1 variety. Whilst, lowest percentage of germination from treated Gemmiza 12 variety with highest salinity level of $160 \mathrm{mmol}$ and the highest mean germination time (5.6) obtained from treating Sakha 94 variety with highest salinity level of 160 mmol. Hamoon, Sorkhtokhm and Bolani cultivars were more tolerant to salt stress than the others were. [12]. Salinity increased the activity of antioxidant enzymes, but inhibit the antioxidant enzyme activities at high concentration or long-term of salt stress [13]. Salinity reduced germination percentages and increased $\mathrm{Na}^{+}$and Cl-concentration in shoots. Sakha 93 and Gemmieza 7 cultivars exceeded Giza 168 cultivar under salinity and water stress [33]. The highest tolerant to salinity were MBB cultivar and Waha cultivar recorded the lowest [14].
Interaction between antioxidants types and
concentration effect

The interaction between antioxidants types and concentration significantly affected percentages of germination and mean germination time, but insignificantly affected energy of germination and germination index. The results graphically demonstrated in Figs. 9 and 10 showed that the highest percentages of germination (93.0\%) obtained from soaking in humic acid at $200 \mathrm{mmol}$ and the lowest mean germination time $(2.6 \mathrm{~d})$ obtained from soaking in ascorbic acid at 200 mmol. Whereas, the less percentages of germination and highest of mean germination time were recorded from without antioxidants at the control. Seeds prim with $50 \mathrm{ppm}$ Ascorbic acids and 50 ppm SA not only improved final germination count, but also under saline conditions reduced time of germination [3]. Potassium humate or deproteinised leaf juice with potassium humate simulated for getting largest seed germination of wheat [4]. All studied antioxidant enzymes were limiting factors of these genotypes and these reasons led to the salt sensitivity in DN-27 cultivar [27].

\section{Interaction between antioxidants types and} salinity levels effect

The interaction between antioxidants types and salinity levels significantly affected percentages of germination and mean germination time, but insignificantly affected energy of germination and germination index. The results graphically demonstrated in Figs. 11 and 12 showed that the highest percentages of germination and the less mean germination time were recorded from soaking in all studied antioxidants and without salinity stress. While, the lowest percentages of germination (73.5) and the higher mean germination time (4.5) were recorded from soaking in Salicylic acid at higher salinity level of $160 \mathrm{mmol}$. The important of salicylic acid at low levels of stress, reducing the time of germination. Seed soaking in salicylic acid at low levels of $7 \mathrm{mmol}$ produced the highest percentage of germination [6]. Humic acid application partly reduced the final germination percentage, the inhibiting effect of salt on the seed germination alleviated in varying degrees by HA pretreatment [30].

\section{Interaction among antioxidants concentrations and salinity levels effect}

The interaction between antioxidants concentrations and salinity levels insignificantly affected percentages of germination, energy of germination, germination index and mean germination time.

\section{Interaction between cultivars $x$ antioxidants types $x$ antioxidants concentration effect}

The interaction among cultivars $\mathrm{x}$ antioxidants types $\mathrm{x}$ antioxidants concentration insignificantly affected percentages of germination, energy of germination, germination index and mean germination time.

\section{Interaction between cultivars $x$ antioxidants types $x$ salinity level effect}

The interaction among cultivars $\mathrm{x}$ antioxidants types $\mathrm{x}$ salinity level insignificantly affected percentages of germination, energy of germination, germination index and mean germination time.

\section{Interaction among antioxidants types $x$ antioxidants concentrations $x$ salinity level effect}

The interaction among antioxidants types $\mathrm{x}$ antioxidants concentrations $\mathrm{x}$ salinity level insignificantly affected 
percentages of germination, energy of germination, germination index and mean germination time.

Interaction among cultivars, antioxidants types $x$ antioxidants concentrations $x$ salinity level effect
The interaction among cultivars, antioxidants types $\mathrm{x}$ antioxidants concentrations $\mathrm{x}$ salinity level insignificantly affected percentages of germination, energy of germination, germination index and mean germination time.

Table 1: Final germination and germination energy \%, as affected by antioxidants types and levels and salinity concentrations of some wheat cultivars as well as their interactions

\begin{tabular}{|c|c|c|c|c|}
\hline $\begin{array}{l}\text { Characters } \\
\text { Treatments }\end{array}$ & $\begin{array}{l}\text { Final germination } \\
\text { percentage }\end{array}$ & $\begin{array}{l}\text { Germination } \\
\text { energy percentage }\end{array}$ & Germination index & $\begin{array}{l}\text { Mean germination } \\
\text { time }\end{array}$ \\
\hline \multicolumn{5}{|l|}{ A-Cultivars: } \\
\hline Sakha 94 & 91.02 & 30.60 & 0.912 & 3.77 \\
\hline Misr 1 & 96.80 & 58.11 & 0.970 & 2.29 \\
\hline Misr 2 & 80.91 & 21.26 & 0.936 & 3.03 \\
\hline Gemmiza 12 & 92.51 & 36.75 & 0.961 & 2.86 \\
\hline F. test & $*$ & $*$ & $*$ & $*$ \\
\hline \multicolumn{5}{|c|}{ B-Antioxidants types: } \\
\hline Humic acid & 91.15 & 40.08 & 0.951 & 2.89 \\
\hline Salicylic acid & 89.33 & 28.75 & 0.933 & $3 \cdot 31$ \\
\hline Ascorbic acid & 90.45 & 41.21 & 0.949 & 2.77 \\
\hline F. test & $*$ & $*$ & * & $*$ \\
\hline \multicolumn{5}{|c|}{ C-Antioxidants levels: } \\
\hline Control & 88.85 & $35 \cdot 35$ & 0.934 & 3.02 \\
\hline $100 \mathrm{ppm}$ & 90.46 & 37.06 & 0.946 & 2.98 \\
\hline $200 \mathrm{ppm}$ & 91.61 & 37.63 & 0.953 & 2.97 \\
\hline F. test & * & & $*$ & $*$ \\
\hline LSD at $5 \%$ & 0.67 & 0.92 & 0.007 & 0.03 \\
\hline \multicolumn{5}{|c|}{ D-Salinity concentrations: } \\
\hline $\mathrm{O} \mathrm{mmol}$ & $95 \cdot 50$ & 65.61 & 1.000 & 2.00 \\
\hline $40 \mathrm{mmol}$ & 94.88 & 57.33 & 0.993 & 2.24 \\
\hline $80 \mathrm{mmol}$ & 92.69 & 38.88 & 0.969 & 2.81 \\
\hline $120 \mathrm{mmol}$ & 90.69 & 19.47 & 0.947 & 3.58 \\
\hline $160 \mathrm{mmol}$ & 77.77 & 2.11 & 0.814 & $4 \cdot 31$ \\
\hline F. test & & $*$ & * & $*$ \\
\hline LSD at $5 \%$ & 0.87 & 1.17 & 0.009 & 0.06 \\
\hline
\end{tabular}

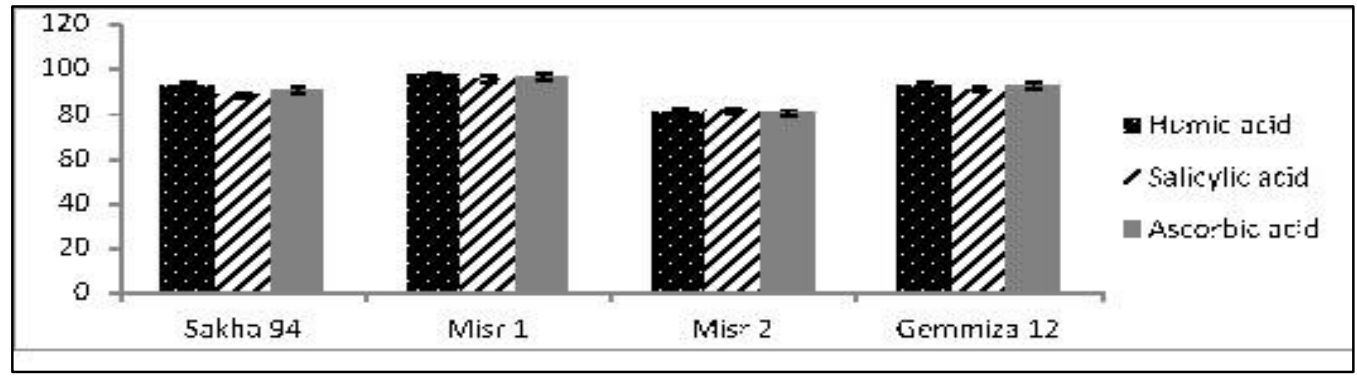

Fig. 1: Percentages of final germination as influenced by the interaction between wheat cultivars and antioxidants types

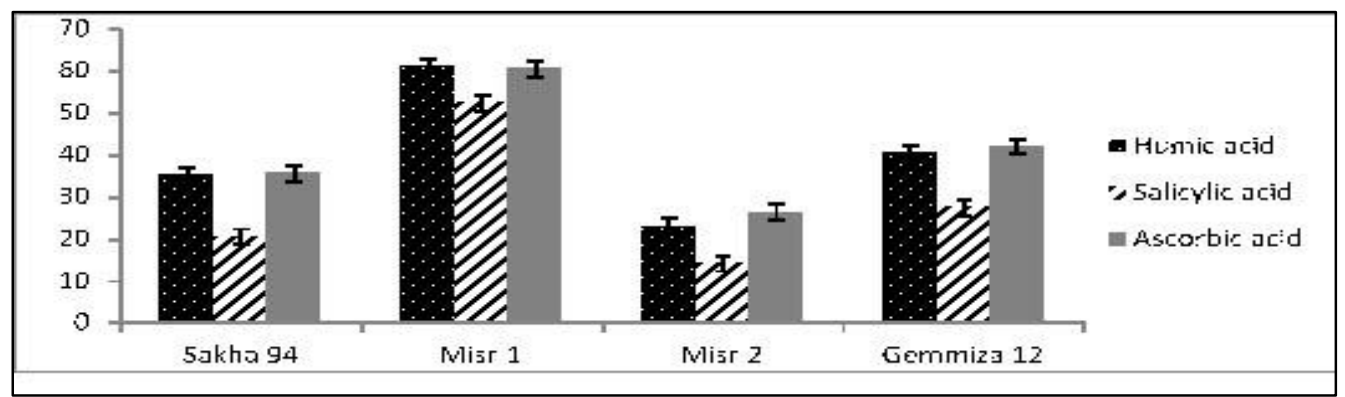

Fig. 2: Averages of germination energy \% as influenced by the interaction between wheat cultivars and antioxidants types 


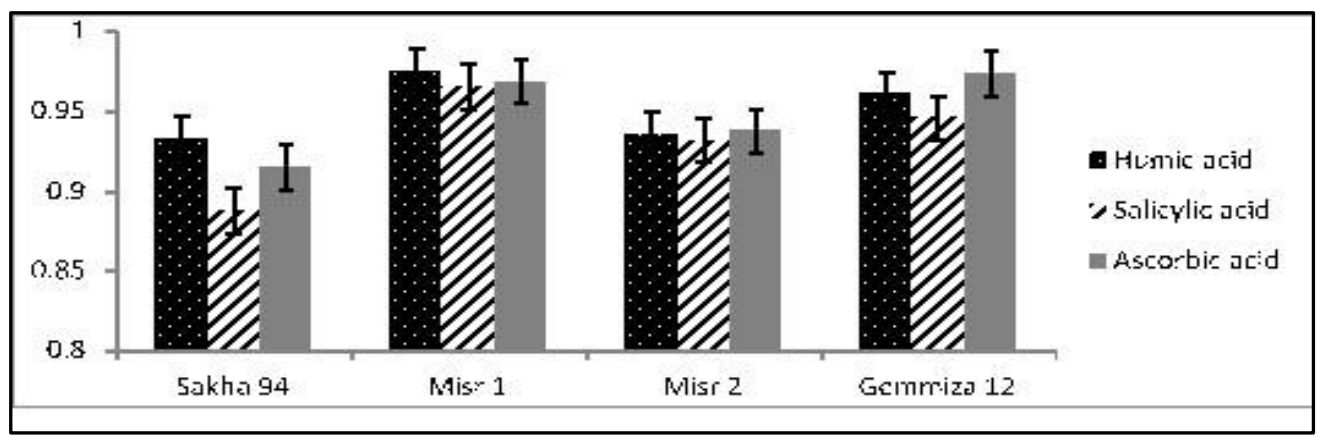

Fig. 3: Averages of germination index as influenced by the interaction between wheat cultivars and antioxidants types

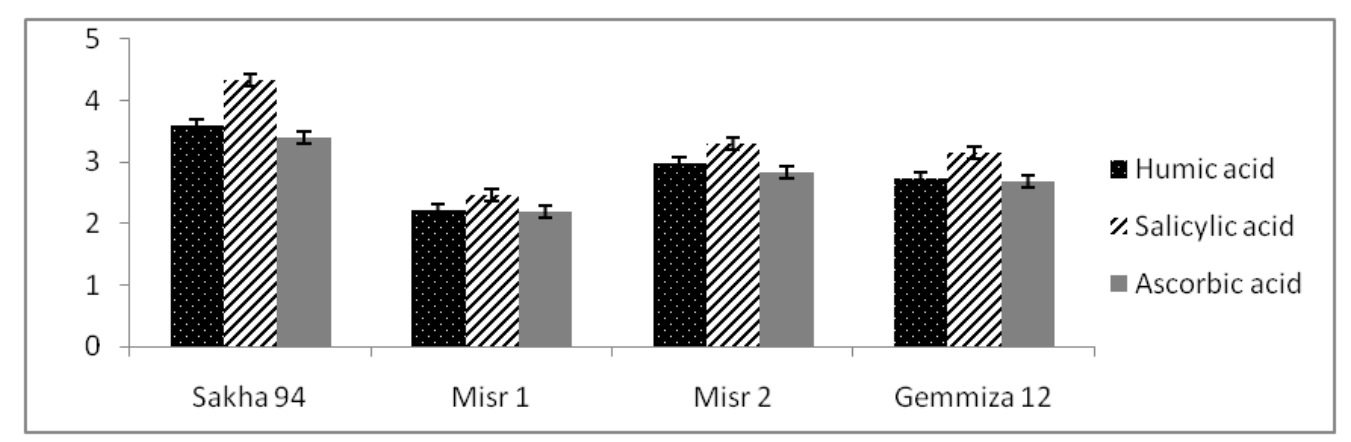

Fig. 4: The mean of germination time as influenced by the interaction between wheat cultivars and antioxidants types

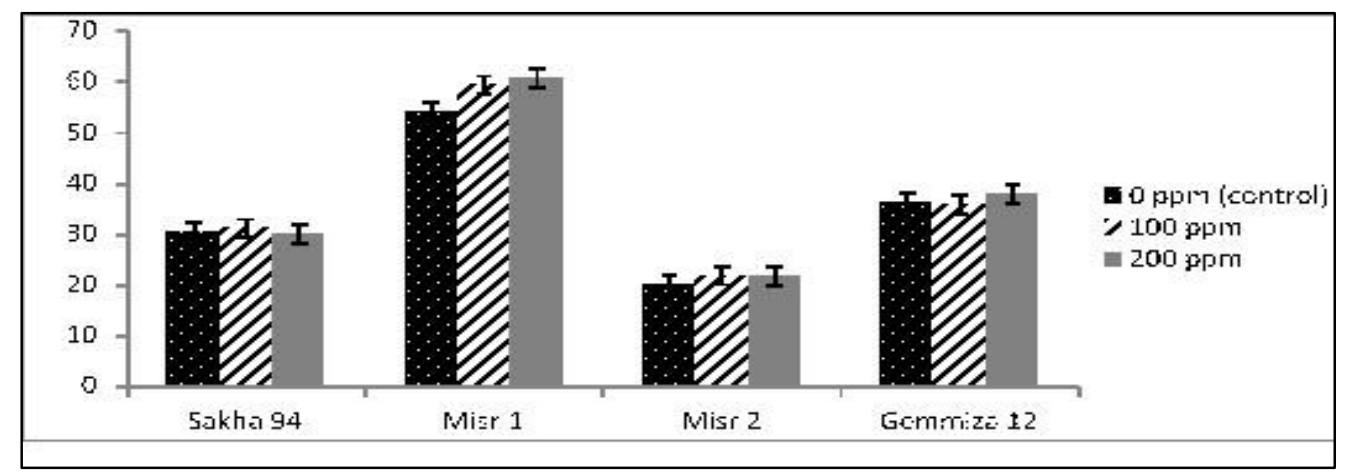

Fig. 5: Mean of germination energy \% as influenced by the interaction between wheat varieties and antioxidants levels

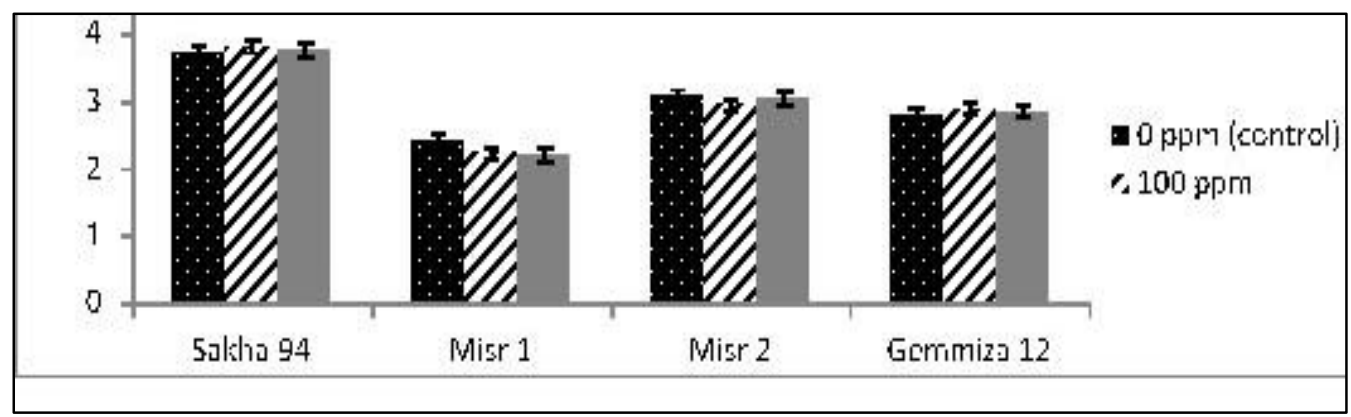

Fig. 6: The mean of germination time as influenced by the interaction between wheat varieties and antioxidants levels 


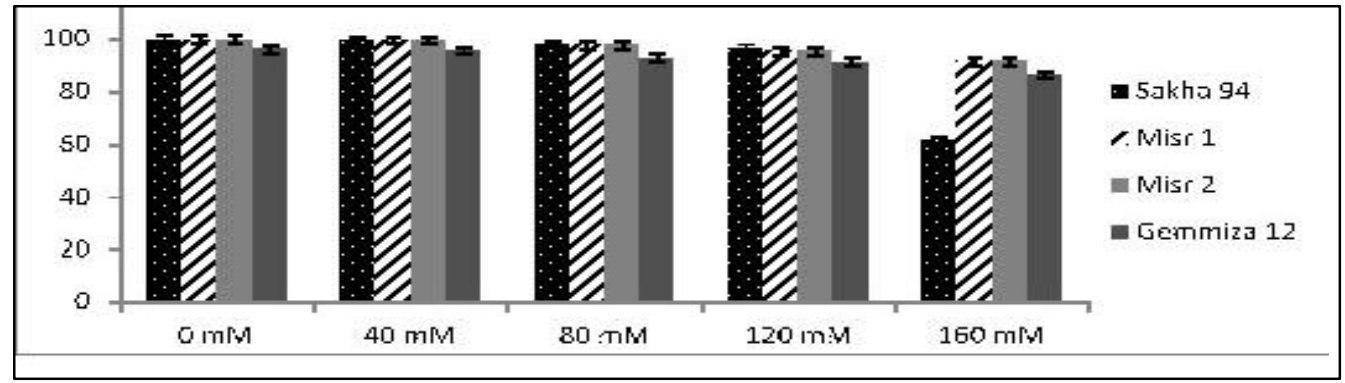

Fig. 7: Percentages of final germination as affected by the interaction between wheat varieties and salinity concentrations

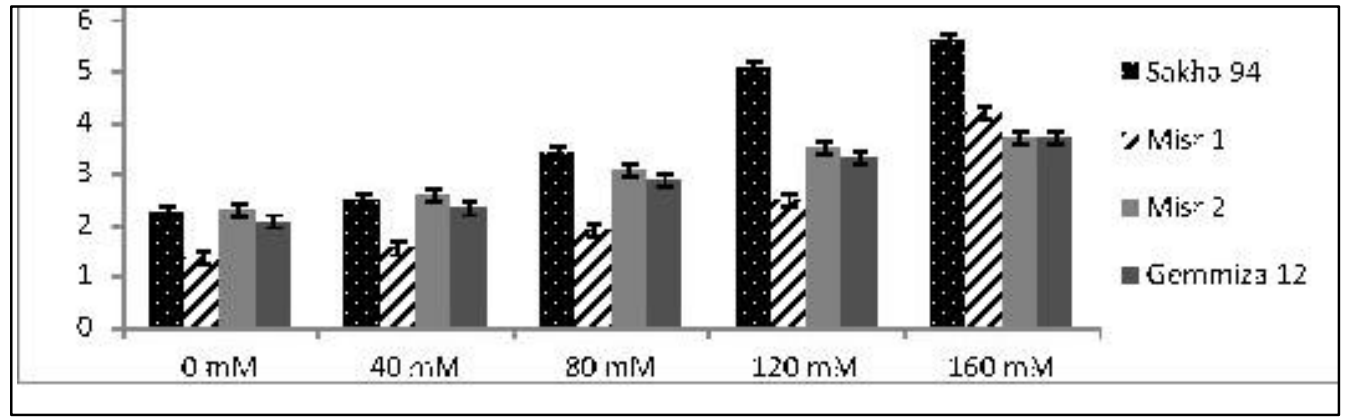

Fig. 8: Average of germination time as influenced by the interactive of wheat varieties and salinity concentrations

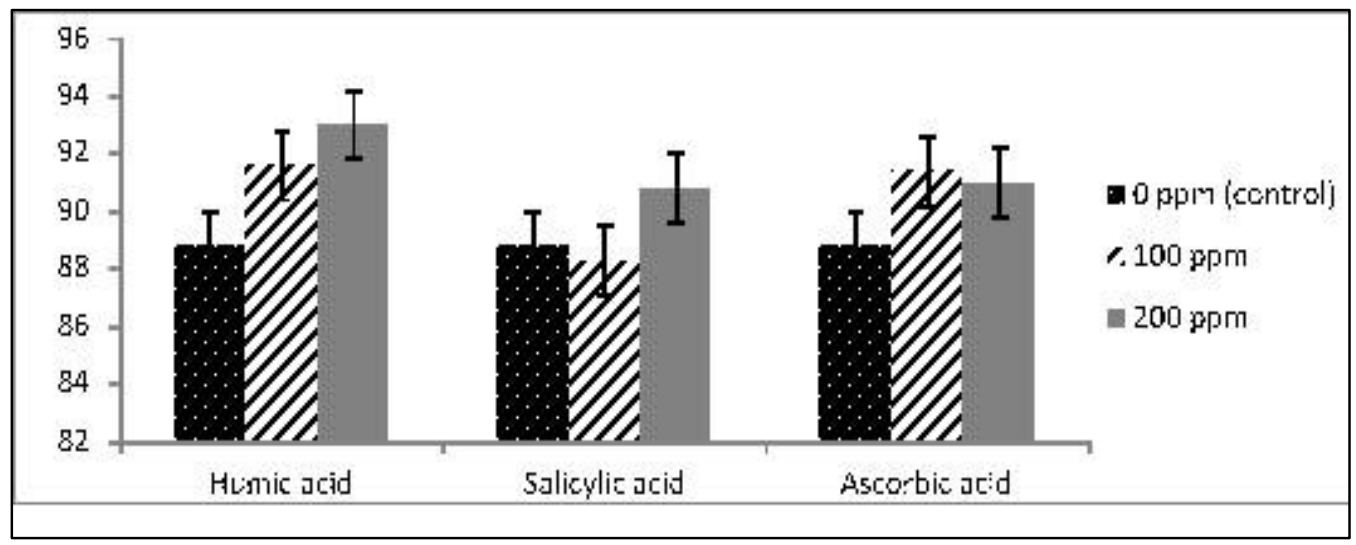

Fig. 9: Percentages of final germination as influenced by the interactive of antioxidants types and levels

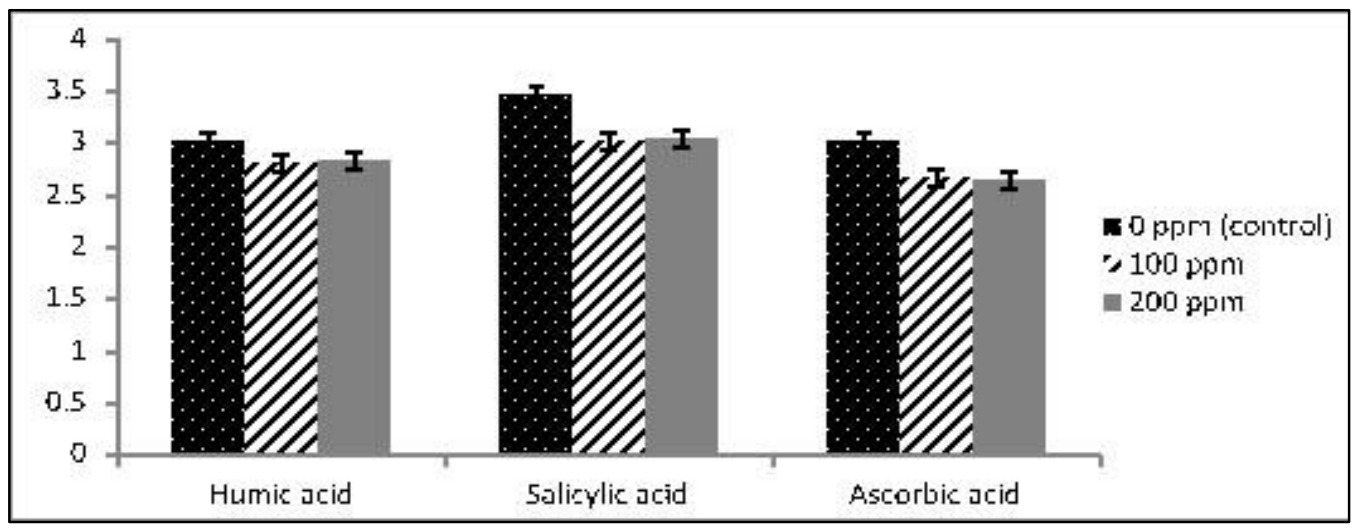

Fig. 10: Averages of mean germination time as influenced by the interaction between antioxidants types and levels 


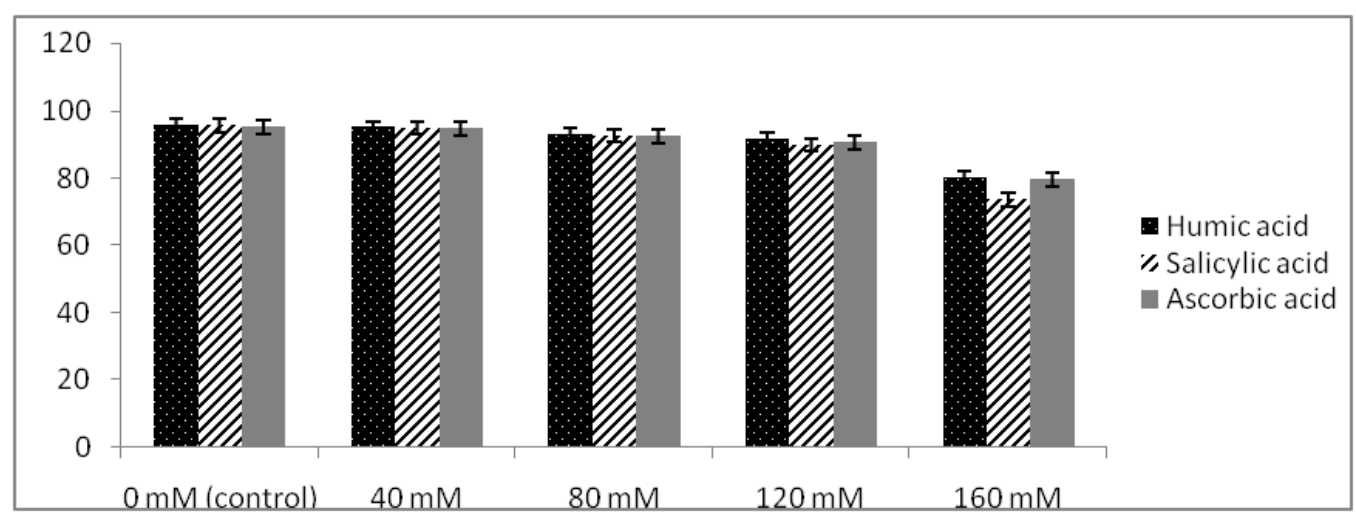

Fig. 11: Averages of final germination $\%$ as influenced by the interaction between antioxidants types and salinity concentrations

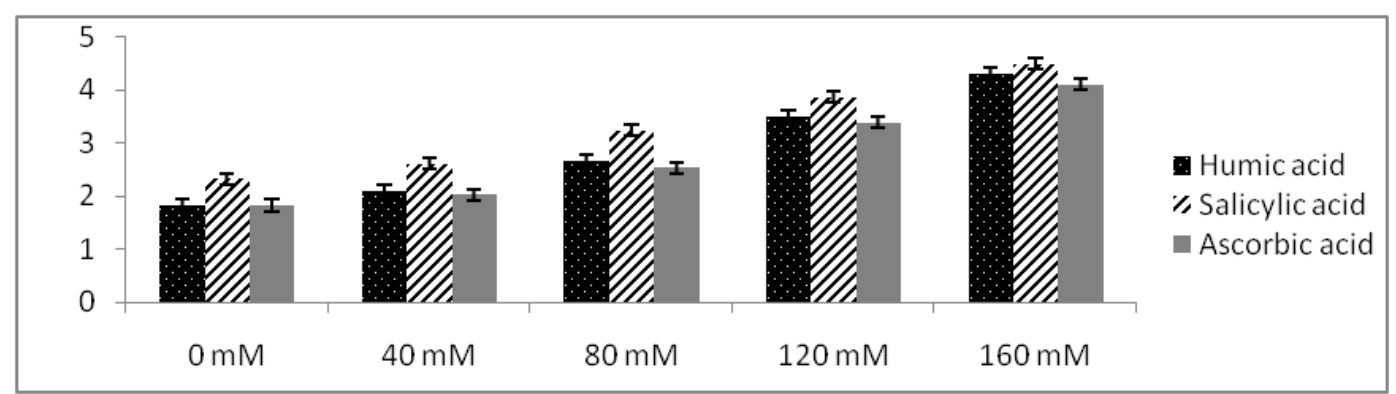

Fig. 12: Averages of mean germination time as influenced by the interaction between antioxidants types and salinity concentrations

\section{CONCLUSION}

Accordingly, for reducing the gap between production and consumption, it could be recommended that soaking bread wheat in humic acid or ascorbic acid at $200 \mathrm{mmol}$ under salinity stress enhanced seed viability and advise to sown under saline new reclaimed soil

\section{REFERENCES}

1. FAO. FAO Food and Agriculture Statistics. Agrestic, 2007. www. fao. org (accessed on 10 June 2010. FAO, 2007.

2. Agarwal S, Sairam RK, Srivastava GC, Tyagi A, Meena RC. Role of ABA, salicylic acid, calcium and hydrogen peroxide on antioxidant enzymes induction in wheat seedlings. Plant Science, 2005;169:559-570.

3. Afzal I, Shahzad MAB, Farooq M, Nawaz A. Alleviation of salinity stress in spring wheat by hormonal priming with ABA, salicylic acid and ascorbic acid. International Journal of Agriculture and Biology, 2006;8: 23-28.

4. Patil R. Effect of Potassium Humate and Deproteinised Juice (DPJ) on seed germination and seedling growth of wheat and Jowar. Annals of Biological Research, 2010;1: 148-151.

5. Movaghatian A, Khorsandi F. Effects of Salicylic Acid on Wheat Germination Parameters under Drought Stress. American-Eurasian J. Agric. and Environ. Sci., 2013;13:1603-1608. DOI: 10.5829/idosi.aejaes.2013. 13.12.12268

6. Sharafizad M, Naderi A, Siadat SA, Sakinejad T, Lak S. Effect of salicylic acid pretreatment on germination of wheat under drought stress. Journal of Agricultural Science, 2013;5: 179-199. DOI:10.5539/jas. v5n3p179
7. Nazi F, Reza H, Rahman R. Effect of humic fertilizer on germination of wheat seeds under drought stress. Advances in Bioresearch, 2014;5: 98-102. DOI: 10.5829/idosi. aejaes.2013.13.12.12268

8. El-Hendawy S. E. Salinity tolerance in egyptian spring wheat genotypes. Ph. D. Thesis, 2004; Technischen Universität München, Germany.

9. Iqbal M, Ashraf M, Jamil A, Rehman S Does seed priming induce changes in the levels of some endogenous plant hormones in hexaploid wheat plants under salt stress? Journal of Integrative Plant Biology, 2006;48,181-189. DOI: 10.1111/j.1744-7909. 2006.00181. $\mathrm{x}$

10. Rahman M, Soomro UA, Zahoor-ul-Haq M, Gul S. Effects of $\mathrm{NaCl}$ salinity on wheat (Triticum aestivum L.) cultivars. World Journal of Agricultural Sciences, 2008;4 :398-403.

11. Datta JK, Nag S, Banerjee A, Mondal NK. Impact of salt stress on five varieties of wheat (Triticum aestivum L.) cultivars under laboratory condition. J. Appl. Sci. Environ. Manage., 2009;13:93-97.

12. Akbarimoghaddam $\mathrm{H}$, Galavi $\mathrm{M}$, Ghanbari A, Panjehkeh N. Salinity effects on seed germination and seedling growth of bread wheat cultivars. Trakia Journal of Sciences, 2011;9: 43-50.

13. Ashraf MA, Ashraf M, Shahbaz M. Growth stage-based modulation in antioxidant defense system and proline accumulation in two hexaploid wheat (Triticum aestivum L.) cultivars differing in salinity tolerance. Flora, 2012;207:388-397. doi. 10.1016/j.flora.2012. 03.004

14. Fercha A, Gherroucha H. The role of osmoprotectants and antioxidant enzymes in the differential response 
of durum wheat genotypes to salinity. Journal of Applied Botany and Food Quality, 2014;87:74-79.

15. Kochak-Zadeh A, Mousavi SH, Eshraghi-Nejad M. The effect of salinity stress on germination and seedling growth of native and breeded varieties of wheat. Journal of Novel Applied Sciences, 2013;2 : 703-709.

16. Mahmoodzadeh H, Khorasani FM, Besharat H. The impact of salt stress on seed germination indices of five wheat cultivars. Annals of Biological Research, 2013;4:93-96.

17. Oproi E, Madosa E. Germination of different wheat cultivars under salinity conditions. Journal of Horticulture, Forestry and Biotechnology, 2014;18 :89-92.

18. AL-Saady HAA. Germination and growth of wheat plants (Triticum aestivum L.) under salt stress. Journal of Pharmaceutical, Chemical and Biological Sciences, 2015;3:416-420.

19. ISTA. Rules, International seed testing association. ISTA Germination Sec. Chapter 19, 2016;19-41.

20. Ellis RA, Roberts EH. The quantification of ageing and survival in orthodox seeds. Seed Sci. Technol., 1981;9:373-409.

21. Ruan S, Xue Q, Tylkowska K. Effects of seed priming on germination and health of rice Oryza sativa $L$. seeds. Seed Science and Technology, 2002;30:451458.

22. Karim MA, Utsunomiya N, Shigenaga S. Effect of sodium chloride on germination and growth of hexaploid triticale at early seedling stage. Japanese Journal of Crop Science, 1992;61:279-284.

23. Gomez KA, Gomez AA. Statistical Procedures in Agricultural Research, John Wiley and Sons, New York 1991.

24. Snedecor GW, Cochran WG. Statistical Methods. $7^{\text {Th }}$ Ed. Iowa State University Press, Iowa, USA, ISBN10:0-8138156o-6, 1980;p: 507.
25. Ahmad M, Shahzad A, Iqbal M, Asif M Hirani AH. Morphological and molecular genetic variation in wheat for salinity tolerance at germination and early seedling stage. Australian J. of Crop Science, 2013;7; 66-74.

26. Biabani A, Heidari H, Vafaie-Tabar M. Salinity effect of stress on germination of wheat cultivars. International Journal of Agric. and Food Sci. Tech., 2013;4: 263-268.

27. Bhutta WM. Antioxidant activity of enzymatic system of two different wheats (Triticum aestivum L.) cultivars growing under salt stress. Plant Soil Environment, 2011;57: 101-107.

28. Kandil AA, Sharief AE, Elokda MA. Germination and seedling characters of different wheat cultivars under salinity stress. Journal of Basic and Applied Sciences, 2012;8:585-596.

29. Alom R, Abu Hasan Md, Islam RMd, Qing-Feng W. Germination Characters and Early Seedling Growth of Wheat (Triticum aestivum L.) Genotypes under Salt Stress Conditions. J. Crop Sci. Biotech., 2016;19 : 383392. DOI: $10.1007 / \mathrm{s} 12892-016-0052-1$

30. Çavuşoğlu K, Ergin HG. Effects of humic acid pretreatment on some physiological and anatomical parameters of barley (Hordeum vulgare L.) Exposed to salt stress. Bangladesh Journal Botany, 2015;44: 591-598.

31. Kaydan D, Yağmur M, Okut N. Effects of salicylic acid on the growth and some physiological characters in salt stressed wheat (Triticum aestivum L.). Tarim Bilimleri Dergisi, 2007;13 :114-119.

32. Ali H, Akbar Y, Razaq A, Muhammad D. Effect of humic acid on root elongation and percent seed germination of wheat seeds. International Journal of Agriculture and Crop Sciences, 2014;7: 196-201.

33. Kandil EE, Schulz R, Müller T. Response of Some Wheat Cultivars to Salinity and Water Stress. Journal of Applied Sciences Research, 2013;9: 4589-4596. 